\title{
INCREASED AGGRESSION AND HARD TIMES, AND MOVING FORWARD AND THIS ISSUE'S CONTENTS
}

The starting point for talking about what is happening in Cuba today, and what people in Cuba are talking about today, has to be that times on the Island are not just hard, but very hard. It is true that, by measures of such daily essentials as food and energy (electricity and petroleum), they are not as bad as during depths of the Special Period, but "not-as-bad-as-the-worst" does not change that they are very hard. Macro-economic figures confirm what anyone living on the Island knows from their daily existence. COVID hit Latin America and the Caribbean hard in 2020, causing an average contraction of 7.5 percent. Cuba contracted 11 percent. The main contribution to this 3.5 percent worse economic performance than the regional average was Trump's dramatic intensification of the Blockade with an additional 242 measures, a Blockade that was already costing Cuba roughly 5 percent of its GDP every year before this injection of steroids.

The difficulty of daily life in Cuba over the last year and a half has received extensive coverage from the usual spectrum of perspectives on "all things Cuban" - from the opponents of Cuba's project to build socialism, from the international press, from the supporters of Cuba's project to build socialism and from the Cuban government. The organisation and visibility of the opponents of the US Blockade around the world, but especially in the US (and its near-neighbour and close ally Canada) where this is particularly important, have both increased markedly. At the same time, Biden has broken his campaign promise to pursue and develop the Obama-Raúl Castro opening, going so far as to add still more Blockade measures (albeit largely symbolic) at the end of July 2021. This brief introductory editorial will not address either of these very important issues, but rather the much less internationally discussed issue: what is Cuba doing today to move the country forward, whether measures already under development for years are being implemented today, or new measures arising directly in response to this crisis? 
While of course there are many more, this editorial will indicate four social and economic issues that are at least among the most, if not the most, discussed by people throughout Cuba today: COVID, food, the economic reforms and the new Families Code.

First, COVID. As this editor wrote in the introductory editorial one year ago, because of its healthcare system, which Cuba had built up as a central pillar of its Revolution over the previous 60 years, the Island had only 88 deaths as of late summer 2020, a per capita rate of deaths (and similarly for infections) less than one-fiftieth (1/50th!) of that of the wealthy US at that time. As in a number of other countries around the world, a government and a population conducting basic preventative medical practices appropriate for a pandemic, such as wearing masks, social distancing, banning large gatherings, lockdowns when needed and so on, was sufficient to maintain this impressive containment of COVID until spring 2021. As the world (including in particular Southeast Asia, much of which had likewise done well against COVID in 2020) subsequently found out, these types of measures are not sufficient to contain the Delta variant of COVID. As of late September 2021 when this is being written, Cuba has now had almost 80 times as many deaths, 6,856. Instead of a per capita rate about 2 percent of that of the US, it now has a per capita rate that is almost 30 percent that of the US. Yes, still impressive for a middle-income Third World country, but a qualitatively different concern than a year ago for Cubans.

As opposed to the variants of COVID before Delta, only vaccination seems able to keep it "under control". Once again (as for example with education and healthcare in general over the last 60 years), Cuba's "different system" has enabled it to do something, in this case life-saving, not available to other small middle-income or poor countries: vaccinate its population. In March 2020 when COVID hit the world, Cuba made a political decision to develop a vaccine against it. This decision itself was only possible because of Cuba's commitment four decades ago to develop a biotech industry, "out of place" for such a small and, compared to the homes of the biotech industry around the world, relatively poor country. The poorest of all the continents, Africa, has an inoculation rate as of now around 4 percent, with no adequate near-term increase in sight. Certainly hundreds of millions more will die there and in other of the poorest countries around the world over the next years from COVID, as they go through this pandemic only minimally vaccinated. The Island is currently inoculating its population with three domestically discovered, developed and produced vaccines (with two further candidates in the pipeline). Despite problems of obtaining enough syringes, once again seriously aggravated by the Blockade, Cuba projects inoculating its entire population by the end of 2021. In line with its commitment to "helping those who are even poorer than we are", Cuba has committed to 
exporting its vaccines to poor countries that cannot pay once it has inoculated its own population. Additionally, it will sell it to those countries that can pay but cannot get it because world supply is not adequate for world demand, and what is being produced by private pharmaceutical companies is prioritised for those countries that can pay the most for it. On 25 September 2021 Cuba announced that it had made its first export of one of its vaccines, the three-shot Abdala vaccine, to Vietnam, which is being ravaged by the Delta variant. This is the first shipment in a contract for five million doses.

COVID is now a central social issue of concern and discussion throughout the population of Cuba.

Second, food. Long lines all over the country for food are perhaps the most immediately visible manifestation of the Island's present crisis, not only to foreign visitors, but to Cubans as well. In the first place, large amounts of time are required from most people in order to obtain their food. In addition the queues concentrate people, contrary to desirable COVID social distancing, even though the majority of time spent in most food lines occurs outdoors. Beyond that, this time spent standing in line does not even assure that one will get the amount of food that one had in 2019; the underlying cause of the queues, of course, is the problem of significantly less food being available than before COVID.

Why are there food shortages? A false narrative frequently asserted by opponents of Cuba's social system claims that Cuba has always had food shortages. In fact, the United Nation's Food and Agricultural Organisation (FAO) had Cuba's national consumption of calories, proteins and fats (the basic measure for the adequacy of food consumption) near First World levels in 1989. In the Special Period in the early 1990s Cuba's food consumption imploded with the rest of the economy, approaching the humanly insufficient permanent levels of Haiti, a situation overcome by the late 1990s. Of 173 countries listed in 2018, the FAO listed Cuba as 31 st in caloric consumption, 79th in protein consumption and 104th in fats consumption. The latter two of these are not First World levels, but they certainly are far from "permanent food shortages because of the system".

Cuba's current food shortages arise from two factors coming together. The first factor is that it is a net food importer. While some countries in the world are net food exporters, many, including both rich and poor countries, are net food importers. This is not a problem for the food supply in food importing countries, as long as they can import what they need. This requires that a country is able to earn enough exporting other goods and services so that it has the means to import the required food, and also that there be no non-economic barriers put up to its necessary imports. The second factor that is currently combined with Cuba's economic structure as a food importing country is exactly that its export earnings from other goods and services have dropped sharply. 
In the first place, like in so many countries in the world, this drop in earnings from the export of goods and services is because of COVID. Contrary to most people's image of Cuba as "highly economically over-dependent on tourism", that industry's' contribution to both employment and GDP is very close to the world average, 10 percent. Pre-COVID the weight of tourism in Cuba's economy was only 30 percent of tourism's weight in the economy of its near neighbour Jamaica, and only 60 percent of the Dominican Republic and even the giant Mexico. It is also lower than that of the developed countries of Spain, Italy and the United Kingdom. (These are official statistics and so do not include black market contributions to tourism in any of the countries considered, which of course can be different amongst them.) But not withstanding that Cuba is not “over tourism dependent", with export earnings of 3.0 billion pesos in 2018 tourism generated about a fifth of Cuba's total goods and services export earnings of 14.5 billion pesos. The world-wide implosion of this industry because of COVID, and in the case of Cuba slightly reinforced by the intensified Blockade from the US, is a major cause of Cuba's current food shortages.

Much less known is that in 2018 Cuba had export earnings from the knowledgebased category of Human Health and Social Care Services over twice those from tourism, 6.4 billion pesos. While earnings in this category come from a number of different service exports, the largest is from the export of medical services. This is a high-quality service that the Cuban economic (and behind that, its social) system produces at low cost, making it extremely competitive by the rules of "free trade" on the world market for medical services. In fact, no other country does, or can, provide this as Cuba does. And so while the COVID pandemic by its nature devastated Cuban tourism, it should have led to a very large increase in the export of its largest earning export, Human Health and Social Care Services.

Therefore, COVID must be seen as the principal cause of that part of the reduction of Cuba's of food availability that resulted from the implosion of tourism, while the intensified Blockade worsened that tourism implosion only very marginally. Contrary to that, the extensive measures directed specifically at blocking Cuba's international medical services is fundamentally the only cause of the part of the reduction of Cuba's food availability that resulted from Cuba's inability to increase its earnings from its greatest export earner, Human Health and Social Care Services. In addition, the Blockade has reduced the ability of Cuba to sell its other exports, and increased the price of both food and other imports, all of which reduces the resources available to Cuba for importing food. Every time the Blockade is brought up as a cause for problems in Cuba, opponents of Cuba's social system like to complain loudly that "the government always uses the Blockade as an excuse for its incompetence and the economic 
non-viability of its system". Notwithstanding their incompleteness, the figures above give support to the claim that the US Blockade is one central cause of Cuba's current major social problem of food shortages, though again certainly sharing this role with COVID.

Given all these problems with importing food, one of the important sets of economic programmes launched this summer concerned various aspects of the institutional, organisational and distributional relations in agriculture. Their goal is to reduce the Island's food dependency in order to increase its food security, given the hostility of the US toward Cuba, and its power in all world economic markets to act on that hostility. The state of Cuba's agricultural production and the related distribution of what its domestic agriculture produces is one major topic of discussion on the streets of Cuba.

Third, the ongoing economic reforms. Given that the international press gives significant coverage to the existence of these ongoing reforms, the only thing that will be stressed here is the fundamental difference of the content of these reforms, as seen by those carrying them out, from the way their content is presented in most of the international press. To the Cuban government, the reforms are intended to "invigorate" the Cuban economy, and to do so in a way that supports and promotes the country's central social goal of, over time, constructing a socialist society. Most of the international press, to the contrary, continually presents these measures as the introduction of aspects of capitalism into an economic system that cannot be either efficient or effective without such capitalist measures. The usually unstated implication in the background of their coverage is that, if Cuba continues to try to improve its economic performance, then in the end the constantly expanding "good capitalist measures", which are the only way such improvements can be made, will eventually push aside all the deadwood of the "old and bad socialist measures", until capitalism is finally fully restored.

Two major groups of reforms have been enacted this year, beyond various smaller reforms and the enactment of legislation for already adopted reforms, which go on continuously. At the beginning of the year the government introduced simultaneously monetary unification, exchange rate unification, a revision of the price structure throughout the economy and a broad and major salary reform. This author has argued (for a number of years) that such a monetary unification and the associated policies is a necessary prerequisite for the whole planned, and still being developed, reform process. Without it, not only are the incentives for all types of economic actors greatly distorted, but even more fundamentally problematic, it is not even possible to evaluate the effects of implemented changes in a system with a dual currency and with multiple exchange rates. It is not true that with that system one was completely blind and any evaluation with 
any real meaning of the value of output was impossible. But it is true that one was evaluating output and its changes looking through a pair of very dirty glasses. Then, as with any reforms when put into practice, even if broad sectors of the population will benefit in the short and medium terms, some people will find themselves worse off than they were before the reforms. Constant small adjustments and "smoothing" must be, and are being, enacted in relation to the changes, and in particular in relation to any of the least well-off sectors of society that are negatively impacted by the changes in the short run. All of this has been another very large topic of discussion and debate on the streets of Cuba this year.

A large number of economic reforms were passed over the summer. Here I will only talk about the very import ones concerning the micro, small and medium enterprises (acronym MIPYMES in Cuba). While some production processes continually gain efficiency as they increase to greater scales, many production processes have much smaller optimal efficacy scales, and suffer diseconomies of scale beyond that. This has been a historically recognised problem in the state economic sector in Cuba since the 1970s. In the international press, the passage of laws supporting the development of MIPYMES has been largely presented as an act to support the development of private MIPYMES. In Cuba, to the contrary, the law was written very clearly; there is a need for part of the state sector to move from oversized firms to MIPYMES just as much as there is an intent to enable the formation of private MIPYMES (the third sector, cooperatives, is basically all on the MIPYMES scale). Besides including a discussion on property forms that is always covered in the international press, the discussion in Cuba on MIPYMES is equally about how to promote an "entrepreneurial mentality" in its production units. Note that the word "entrepreneur" is not a synonym for "capitalist", as it is generally used by people in favour of that system. Rather, a dictionary definition of "entrepreneur" is "a person who organizes and manages any enterprise, especially a business, usually with considerable initiative". There is no mention in the definition of state property vs private property. It is clear from the definition of the word that an "entrepreneurial mentality" is a requirement for any productive unit to be truly economically successful, particularly over time. In line with much economic theory around the world, Cuba believes that the scales and structures of MIPYMES could be greatly superior for promoting this necessary mentality in management, including in state enterprises, for at least many productive processes.

The misunderstandings and misrepresentations by much of the international press concerning the nature of the current process of change in Cuba is stressed in this editorial because its goal, like that of this journal, is to understand "all things Cuban". Regardless of whether Cuba's changes will end up yielding the results their protagonists intend, and certainly regardless of observers' views on the desirability 
of socialism, it is not possible to understand what is happening now in Cuba if one does not understand what the Cubans who are directing the changes intend for them to accomplish. Future changes intended to continually adjust the ongoing process of change will obviously likewise be strongly affected by what those intentions are.

Fourth, the Families Code (note the plural). As many readers know, the original proposal for the 2019 Constitution that was presented as a draft to the population for discussion contained proposals on the family, and specifically on matrimony, intended to establish the legal equality of same-sex marriage and families they created with those of heterosexual spouses. In the national discussion of that original proposal for the new constitution, organised to generate direct popular input into modifying it before a final proposal was voted on by the population, this was the most discussed issue. There was significant opposition to it, organised in the first place by the churches in Cuba, but also by other social groups in accord with their (in addition to religion) traditions, culture, ideology, etc. The government concluded that there was significant social disagreement on this issue and that therefore further social discussion was appropriate, and so removed those clauses from the proposed 2019 Constitution, which was subsequently overwhelming popularly ratified.

This proposed nationally organised discussion of these issues has just begun to unfold as this editorial is being written. The new Families Code will replace the Family Code that was adopted on 8 March 1975, after more than half a year of organised national popular discussion and input into that final document. The first draft of the new Families Code, created by a team of 31 experts and containing more than 480 articles, was released on 15 September 2021. The website of the Justice Ministry will collect opinions on this for several months, after which it is will go to lawmakers, probably in December. This writer feels that probably it will also go to a popular referendum early next year.

There is an extremely interesting conceptual issue concerning adopting such legislation for a government that considers itself both revolutionary, and hence protagonistic in regards to human rights for all, and reflective of the popular will. To achieve the latter, they will, as is normal for things like this in Cuba, modify their original proposals in accord with the popular input that they actively collect. However, a number of Cuban activists on this issue fear that, given what happened in response to the popular input in 2018 for the Constitution on this issue, the result could be deep modifications that render the proposed Families Code no longer committed to complete legal equality. Some argue that because what is involved is a fundamental human right this should not be subject to popular opinion or a referendum, and to the contrary that the government should simply impose it. The government, in line with its other goal of acting in accord with the will of the people, argues that it is important to build a social consensus concerning the 
correctness of this legislation, as opposed to imposing it on people who disagree with it. One thing that seems certain is that, based on the intensity of the controversy on this in 2018, this will certainly be a major and intense issue of debate on the streets of Cuba, and even more so in people's homes, over the fall.

While the International Journal of Cuban Studies publishes articles only in English and Spanish, there is an academic literature on "all things Cuban" in all major languages of the world. Three in Europe besides English and Spanish that are particularly substantial are French, Italian and German. The first three of the academic articles in this issue constitute a small dossier of works by scholars from the Francophone world. With no pretensions of this being "an introduction to the French academic literature on Cuba" (for which, esteemed readers, you will have to learn French), these are presented as an introduction to the work of three wellknown Francophone Cuban studies scholars, as a small indication of that larger body of work that is beyond what this journal regularly draws from.

The first article is by Rémy Herrera, a scholar at the CNRS and University Paris 1 Pantheon-Sorbonne. While his work in general has a broader focus on radical processes in Latin America of which the process in Cuba is only one (and over the last five years, also on China), he has written a plethora of articles on Cuba over the last two decades. His large two-volume work on Cuba came out in 2003 and 2006, Cuba révolutionnaire - Histoire et culture and Cuba révolutionnaire-Économie et planification, respectively. This work, "De los ciclos de no especialización a la era del azúcar. Elementos de historia de Cuba en un largo período (1492-1898) (PARTE I)", is the first of a brief two-part economic history of Cuba highlighting (though certainly not restricted to) three themes: the Island's colonial status throughout, first to Spain and then to the US, the difference in its economy before and after its thorough domination by sugar, and the role of slavery in both the presugar and sugar eras, and the partial change in its nature with that change.

The second article is by Salim Lamrani, a scholar at the University of Reunion who has published a number of times in this journal in the past (most recently, "Fidel Castro, Hero of the Disinherited" in volume 8(2), 2016). Much of his work on Cuba focuses on is relations with the US, and two of his books are available in English: The Economic War Against Cuba: A Historical and Legal Perspective on the U.S. Blockade and Cuba, the Media and the Challenge of Impartiality, 2013 and 2015 respectively. As the author submitted the article in both English and Spanish with the required academic form and quality (the IJCS does not have a budget for translating articles) it appears here in both languages: "Cuban Emigration to the United States, Part 1, from 1860 to 1989: A Statistical and Comparative Analysis" and "La emigración cubana hacia los Estados Unidos, 
Parte 1, de 1860 a 1989: un análisis estadístico y comparativo”. This continues his work on Cuban-US relations through a lengthy consideration of migration, considering both before and after the Revolution, and through comparing it with the migratory flows from other countries of the region.

The final article in the dossier is by Violaine Jolivet and Mateo AlbaCarmichael, scholars at the University of Montreal. Besides articles on Cuban immigration and particularly on Cuban immigrants in Miami, lead author Jolivet has a book on the latter, Miami la cubaine. Géographie d'une villecarrefour entre les Amériques. As with the preceding work by Lamrani, the authors submitted the article in both English and Spanish, and so it appears here in both languages: "Reinvesting in Havana. Housing Commodification and Gentrification in the Central Neighbourhoods of a Socialist City in the Global South" and "Reinvertir en la Habana. Mercantilización de la vivienda, y aburguesamiento en los barrios céntricos de una ciudad socialista del sur global". As indicated by its title, this work considers the process of commodification of housing in Havana after 2011.

The fourth academic article is by Mark Ginsburg, a scholar at University of Maryland - College Park. This work, "Constituting Socialism for the Twenty-First Century: Examining Cuba's 2019 Constitution”, considers Cuba’s new constitution from a very specific perspective. Cuba's new constitution comes out of 60 years of Cuban Revolutionary practice, Castroism, Martiism, Marxism and Leninism. Twenty-first-century socialism comes out of rejecting Marxism and Leninism as interpreted by the USSR from the time of Stalin onward, and going back especially to the works of Marx and Engels as a frame for a desirable socialism. This article considers Cuba's new constitution from the perspective of how consistent it is with the ideas of twenty-first-century socialism.

The final academic article is by the particularly well-known US academic writer on many different aspects of Cuban reality, H. Michael Erisman, a scholar at Indiana State University. The work "Cuba's Roswell Connection: A Crack in the Economic Door?" uses a case study to consider the question: what would it take to improve overall US-Cuba relations through the improvement of US-Cuba trade relations? The first quarter of the article gives an overview of the bad nature of their relations in general for 60 years, then a short section reviews the US barriers to trade, and after that the remainder of the paper details the development of the biotechnologybased trade relations that were developed between Cuba's Centro de Inmunología Molecular (CIM) in Havana and Roswell Park in the US from 2011 forward. 